\title{
Research \\ Hunting for Livelihood in Northeast Gabon: Patterns, Evolution, and Sustainability
}

\author{
$\underline{\text { Nathalie van Vliet }}^{1}$ and $\underline{\text { Robert Nasi }}^{1}$
}

\begin{abstract}
We suggest an ethno-biological approach to analyze the cultural and social drivers of hunting activities and assess sustainability in villages near Makokou, northeast Gabon, based on interviews with hunters, participatory mapping of hunting territories, and daily records of offtakes for 1 yr. Hunting in villages of northeast Gabon is practiced for both local consumption and cash income to cover basic family expenses. There appears to be no clear tendency to abandon subsistence hunting for commercial hunting as in other regions of Africa. Cultural and socioeconomic factors explain the temporal and spatial variation in hunting activities. Hunting increases in the dry season during circumcision ceremonies, when it is practiced mainly at $>10 \mathrm{~km}$ from villages, and decreases during the rainy season because most hunters are occupied by other economic activities. Degraded forest such as secondary regrowth supplies $20 \%$ of the animals killed and the greatest diversity of species at short distances from villages. Mature forest supplies the species with the greatest commercial value, e.g., red river hog (Potamochoerus porcus), and is the preferred source of meat for traditional ceremonies. In the last $15 \mathrm{yr}$, hunting patterns have changed rapidly, mainly because of the spread of gun hunting, which had serious implications for the nature of offtakes. Our results suggest that there is potential to allow hunting for resistant species such as blue duiker (Cephalophus monticola) and African brush-tailed porcupine (Atherurus africanus). Other species such as red river hog and small diurnal monkeys require more attention. Specific management systems could be discussed in participatory hunting management plans to identify possible solutions to maintain the population levels of the more critical species.
\end{abstract}

Key Words: ethno-biological approach; hunting impact; hunting practices; northeast Gabon; spatial and temporal patterns; sustainability assessments

\section{INTRODUCTION}

Several studies have documented bushmeat as the main source of dietary protein and one of the most important sources of income for rural people in Central Africa (Lahm 1993, Wilkie and Carpenter 1999, Bakarr et al. 2001), where the current annual harvest could exceed two million tonnes ( $\mathrm{Fa}$ et al. 2003). Hunting has been specifically identified as a threat for 84 mammalian species and subspecies from West and Central Africa (International Union for Conservation of Nature [IUCN] 2000, as cited in Bowen-Jones et al. 2002) and 60\% of the mammal species might be hunted unsustainably ( $\mathrm{Fa}$ et al. 2002). With human population growth in the region at $2-3 \%$ annually, if patterns of bushmeat consumption do not change, the demand for bushmeat will double in $<20 \mathrm{yr}$, and large-bodied species could be hunted to local extinction in many forests by 2020 (Wilkie et al. 2005). The bushmeat crisis is first and foremost a problem resulting from the unsustainable harvest of an unmanaged common resource because of inadequate governance and policy frameworks. As such, it should be considered as a facet of the "tragedy of the commons" and be dealt with in the broader framework of adaptive management of renewable natural resources such as timber or fuelwood (Nasi et al. 2008).

During the last decade, a growing number of researchers have tried to determine the effects of hunting and the level at which it appears unsustainable in the Central African countries of Democratic Republic of Congo (Hart 2000, de Merode et al. 2004), Central African Republic (Noss 1998a,b, 2000), Gabon (Feer 1993, 1996, Lahm 
1993), Cameroon (Dethier 1995, Delvingt et al. 1997, Muchaal and Ngandjui 1999, Ngandjui and Blanc 2000, Bousquet et al. 2001, Willcox and Nambu 2006), and Equatorial Guinea (Fa et al. 1995, 2005). Assessments of hunting sustainability in Central Africa have generally used the formula proposed by Robinson and Redford (1991), which is based on biological parameters such as animal density, productivity, and offtake rates. Sustainability has generally been considered from an ecological viewpoint and understood as the maintenance of adequate populations (i.e., able to reproduce and sustain external shocks) of all hunted species.

However, sustainability is more complex, and such biology-based indices fail to properly assess hunting sustainability (Milner-Gulland and Akçakaya 2001, van Vliet and Nasi 2008a) because they are plagued with large uncertainties in parameter estimates and ignore the sociological and economic dimensions that drive ecological sustainability. Some locations that have a long history of hunting and mature markets could appear to be sustainable because they generally have gone through extinction filters whereby the most vulnerable species, generally large-bodied specialists, disappeared to the profit of more resilient species such as small generalists. The Takoradi market in Ghana shows that large urban centers can be sustainably supplied with bushmeat over several decades by robust species from an agricultural landscape (Cowlishaw et al. 2004).

We suggest a combined ethno-biological approach to describe the evolution of hunting practices, highlight the spatial and temporal distribution of hunting effort, and assess hunting sustainability in northeast Gabon. To assess hunting patterns and their evolution, we describe practices and analyze offtakes in selected villages. We highlight changes in hunting practices and in the nature of offtakes during the last $15 \mathrm{yr}$ by comparing our data to those collected by Sally Lahm in the late 1980s in the same region (Lahm 1993). We describe the distribution of hunting effort throughout the year by the number of active hunters and the amount of biomass extracted per month. We also analyze the spatial distribution of hunting effort across the hunting territory using an index of effort per habitat type and by measuring the effort relative to the distance to the village. Finally, we use three different approaches to assess the impact of hunting on mammal species: the number of captures per species in relation to the distance from the village; the evolution of the proportion of large mammal species in total offtakes in the last $15 \mathrm{yr}$; and Robinson and Redford's (1991) index for the three most hunted duiker species: blue duiker (Cephalophus monticola), Peter's duiker (C. callipygus), and bay duiker (C. dorsalis).

Compared to purely biological approaches to measuring hunting impacts, our combined approach gives a better understanding of the cultural and social drivers of hunting activities. This approach can therefore better address the potential for change or better management to guarantee local livelihoods while meeting conservation goals. Given the importance of wildlife for the livelihoods and cultural values of rural populations in northeast Gabon, the results of this type of study can help to clarify the Gabonese forest code, which is unclear concerning customary rights and traditional hunting practices.

\section{METHODS}

Our study was conducted around the city of Makokou, Ogooué-Ivindo Province, northeast Gabon. Ogooué-Ivindo, the largest province in Gabon at $46,075 \mathrm{~km}^{2}$, remained neglected by economic development until the late 1990s; however, with the increase in logging activities in the past $10 \mathrm{yr}$ and the opening of a large open-cast iron mine project, the region is expected to undergo rapid economic development and population growth. The total population was estimated at 64,163 inhabitants in 2003 (Anonymous 2005), with the four urban areas of Makokou (15,508 people), Booué (6144 people), Mékambo (4971 people), and Ovan (3000 people) giving a population density of 1.4 people $/ \mathrm{km}^{2}(0.7$ people/ $\mathrm{km}^{2}$ in rural areas). Three major ethnic groups, i.e., the Fang, Kwelé, and Kota, coexist; the Ba-Kota represent the bulk of the population (Vandeweghe 2006). Of the 13 National Parks created by the Gabonese government in 2002, Mwagna National Park $(115,500$ ha) is totally contained within the province, and three others are partially contained within the province: Minkebe National Park (670,000 ha), Lopé National Park (450,000 ha), and Ivindo National Park (300,000 ha).

From April to December 2005, we studied hunting practices in 11 villages (Figure 1) located $<70 \mathrm{~km}$ from the city of Makokou, along the roads to Libreville (three villages), Bélinga (two villages), and Okondja (six villages). We used a semi- 
structured questionnaire to interview 93 hunters about their hunting techniques, the species hunted, and the spatial and temporal distribution of their hunting activities (Appendix 1).

This work allowed us to select the village of Ntsieté, located $30 \mathrm{~km}$ from Makokou, in which to monitor hunting offtakes for $1 \mathrm{yr}$ from March 2006 to February 2007. We chose Ntsieté because the local population agreed to participate in our long-term study. Offtakes were recorded for all 16 hunters in the village every other day. We documented: the hunting location (name of the camp or river); the time spent hunting; the hunting technique used; and the species hunted, including the sex, type of forest in which the individual was killed, and whether it was used for self-consumption or sale (Appendix 2). This information was used to generate data on: the proportion of gun and snare hunters, the proportion of game used for self-consumption or sold for income, the number of active hunters and the biomass extracted each month, and the preferred habitat types for hunting activities.

A participatory mapping exercise was conducted in Ntsieté to map the hunting territory, including hunting trails and camps. Several field visits allowed us to reference the trails and camps using a Global Positioning System. The map was used to position all hunting trips from the village. This allowed us to assess the spatial heterogeneity of hunting pressure in Ntsieté by comparing hunting pressure at different distances from the village and calculating an index of hunting pressure for each habitat as the ratio of kills per habitat to the availability of each habitat:

$I_{h}=\left(n_{h} / N\right) / p_{h}(1)$

where $n_{h}$ is the number of kills in habitat $h ; N$ is the total number of kills; and $p_{h}$ is the proportion of each habitat within the hunted area, calculated using MapInfo 6.5®.

We used three different approaches to assess the impact of hunting on mammal species. First, assuming that as the impact of hunting increases, mammal species are killed farther away from the village, we measured kills in relation to the distance from Ntsieté. The index of kills was calculated as the ratio of kills per species at various distance classes to the proportion of hunting trips that occurred at each distance class:
$I_{d}=\left(n_{d} / N\right) /\left(t_{d} / T\right)(2)$

where $n_{d}$ is the number of individuals of a given species killed at distance class $d, N$ is the total number of individuals killed of that species, $t_{d}$ is the number of hunting trips at distance class ${ }_{\mathrm{d}}$, and $T$ is the total number of hunting trips.

Second, because a decrease in the proportion of large-bodied species in offtakes can be used as an indicator of the impact of hunting (Fa et al. 2000), we compared previous (Lahm 1993) and our data for the proportion of each species in the total offtake in Ntsieté using the $\chi^{2}$ test.

Third, we calculated Robinson and Redford's (1991) index of sustainability for blue, Peter's, and bay duiker. The maximum sustainable yield (MSY) is equal to the maximum production $\left(P_{\max }\right)$ multiplied by a hypothetical adjustment factor that accounts for pre-reproductive and adult reproductive mortality. Considering that the longevity of duiker is between 5 and $10 \mathrm{yr}$, the adjustment factor is 0.4 , and MSY $=0.4 \times P_{\max }$. The term $P_{\max }$ is calculated as

$P_{\max }=\left(e^{r} \max -1\right) \times D(3)$

where $D$ is the density of the species, and $r_{\max }$ is the maximum rate of increase of the population. We used the formula of Caughley and Krebs (1983), in which $r_{\max }$ is solely a function of the mean population weight $P$ in kilograms.

$r_{\max }=1.5 \times P^{-0.36}(4)$

Following the methods of Feer (1996), we used 75\% of the mean adult weight as the mean population weight (Table 1). Because the population density is difficult to measure in the field, Robinson and Redford (1991) suggest using a predictive value of $D$ based on the carrying capacity $K$. For species that do not breed until late in life, the maximum productivity occurs at $D=0.6 \times K$. Thus,

$P_{\max }=\left(e^{r} \max -1\right) \times D=\left(e^{r} \max -1\right) \times 0.6 K(5)$

For the value of $K$, we used data from Feer (1996) that were obtained through capture-mark-recapture methods (Table 1). The maximum productivity was considered constant throughout the year and at all distances from the village. 
Fig. 1. Eleven villages near the town of Makokou in which we interviewed hunters about their hunting practices.

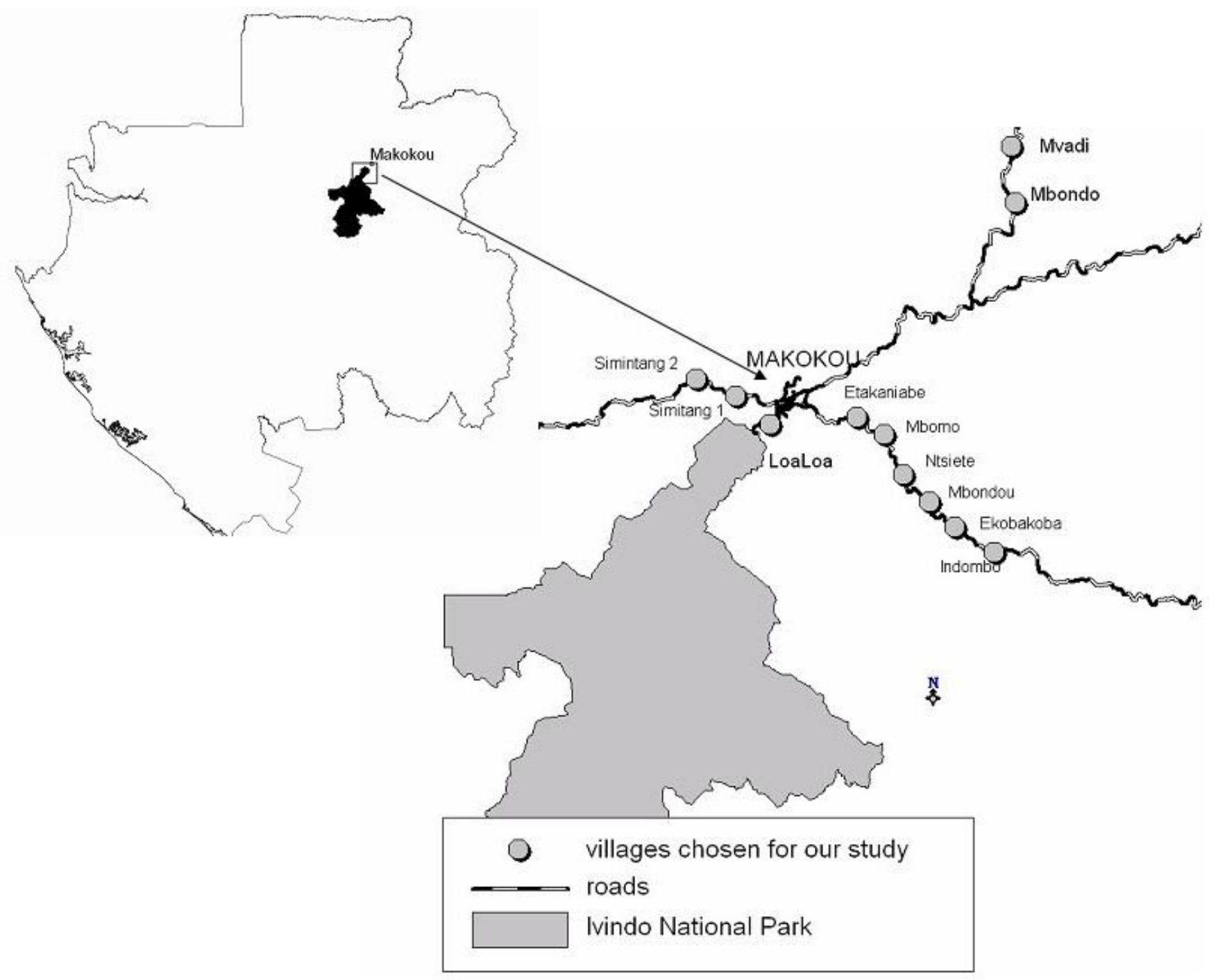

\section{RESULTS}

\section{Hunting practices}

In the 11 villages that we visited, $70 \%$ of the hunters were "village-based hunters" according to the typology of Okouyi (2006). These hunters lived permanently in the village and hunt for subsistence purposes, either for self-consumption or to earn cash for primary expenses. The other $30 \%$ of the hunters were "specialized hunters" (Okouyi 2006), who targeted mainly certain valuable species such as red river hog (Potamochoerus porcus) for meat and elephant (Loxodonta africana) for ivory.

Hunting around Makokou was essentially practiced with guns. In Ntsieté, $85 \%$ of the recorded hunting trips used guns. Cable snares were used only by hunters $>45 \mathrm{yr}$ old. Only $15 \%$ of the hunters used snares at least once from March 2006 to February 
Table 1. Population and harvest characteristics for three species of duiker.

\begin{tabular}{|c|c|c|c|c|c|c|c|}
\hline Species & $\begin{array}{l}\text { Mean pop- } \\
\text { ulation we- } \\
\text { ight }(\mathrm{kg})\end{array}$ & $\begin{array}{c}\mathrm{K} \dagger \\
\text { (individuals/ } \\
\mathrm{km}^{2} \text { ) }\end{array}$ & $\underset{\left(\mathrm{kg} / \mathrm{km}^{2}\right)}{\mathrm{D} \ddagger}$ & $\mathrm{r}_{\max } \S$ & $\begin{array}{c}\mathrm{P}_{\max }{ }^{1}-2 \\
(\mathrm{~kg} \mathrm{~km}-1 \\
\left.\mathrm{yr}^{-1}\right)\end{array}$ & $\underset{\left(\mathrm{yr}^{-1}\right)}{\operatorname{MSY})^{-2}}$ & $\begin{array}{c}\text { Observed annual } \\
\text { offtake } \\
\left(\mathrm{kg} \mathrm{km}^{-2} \mathrm{yr}^{-1}\right)\end{array}$ \\
\hline Peter's duiker & $17.8 \#$ & 10.7 & 100.78 & 0.56 & 70.44 & 28.18 & 19.12 \\
\hline Bay duiker & $17.8 \#$ & 7.1 & 65.60 & 0.56 & 45.85 & 18.34 & 12.94 \\
\hline Blue duiker & $4.23 \dagger \dagger$ & 70 & 155.40 & 0.94 & 223.01 & 89.21 & 24.06 \\
\hline
\end{tabular}

$\dagger$ Carrying capacity (Feer 1996).

$\ddagger \mathrm{D}=60 \%$ of $\mathrm{K}$.

$\S$ Maximum rate of population increase.

¡Maximum annual production.

IIMaximum sustainable yield.

\#Dethier and Ghuirghi (1999).

$\dagger \uparrow$ Noss $(1998 b)$.

2007, and the mean number of snares per hunter was 15 . Only one hunter had a large number of snares (120 snares) that he used for 3 months. Snares were used $<2 \mathrm{~km}$ from the villages, mostly around plantations or in secondary forests. For snare and gun hunters, cable and cartridge supplies were not a limiting factor because they were abundantly available in the markets of Makokou. Hunters reported that cable snares have been abandoned because snare hunting is a labor- and timedemanding technique: Setting a line of 50 snares takes 1 day, and all snares must be checked and reset every 3 days for at least 3 months.

The proliferation of guns has made the rhythm of hunting extremely variable, with periods during which hunters went to the forest every day and long periods during which they stayed at the village or were busy with other activities. When guns were used, some species were hunted using the call of a distressed duiker. The hunter hides behind a large tree or in a semi-dense understorey and calls for 3$4 \mathrm{~min}$. The call triggers surrounding duikers to either run toward or discreetly approach the call point. This technique was mainly used during the day, but was also practiced at night. According to offtake records from Ntsieté, this technique is particularly efficient for ungulates, especially duikers (blue, Peter's, and bay duiker), but also attracts other species such as gorilla (Gorilla gorilla), small diurnal monkeys (Cercopithecus cephus, C. nictitans, C. pogonias, and Lophocebus albigena), and red river hog.

Hunting at night with guns was generally practiced $<5 \mathrm{~km}$ from the village. Leopard (Panthera pardus) and other small nocturnal carnivores such as Felis aurata, Herpestes spp., Genetta spp., Civettictis civetta, Nandinia binonata, Bdeogale nigripes, Poiana richardsoni, and crocodile (Osteolaemus tetraspis) were almost always killed at night. Hunting at night offered a poorer diversity of prey than does hunting during the day: 15 species were killed during the day versus 8 species during the night. However, hunters reported that hunting at night is more efficient than during the day because animals freeze when they are detected using a light.

In 2006-2007, 40\% of the annual offtakes from Ntsieté was sold and the rest was shared within the family. During the dry season, most game was consumed in the villages, mostly during circumcision ceremonies at holiday time. Game that was not consumed with the family was either sold in pieces to other families within the village or to 
people in passing vehicles. Some species were more likely to be sold than others: sitatunga (Tragelaphus spekei; $80 \%$ ), blue duiker $(50.4 \%)$, Peter's duiker (43.7\%), bay duiker (47.6\%), and red river hog (45.6\%). Rodents, reptiles, birds, carnivores, and small monkeys were mostly eaten within the family. Other species were not consumed or were consumed by specific groups of people. For example, yellowbacked duiker (Cephalophus sylvicultor) and whitebellied duiker (Cephalophus leucogaster) were consumed only by the elderly because cultural taboos ban young men and women from eating the meat of these species.

\section{Spatial and temporal variation in offtakes in Ntsieté}

The total hunting territory of Ntsieté was estimated at $44.5 \mathrm{~km}^{2}$. However, hunting pressure was only exerted along hunting trails (Figure 2). Therefore, small and medium-sized territorial mammals were directly affected only if their territory overlapped one or more hunting trails. At $<10 \mathrm{~km}$ from the village, each family used own main and secondary trails. Traditional ownership is defined by historical rights in a certain portion of forest. At $>10 \mathrm{~km}$ from the village, trails and camps were used commonly by all hunters. Not all trails were used simultaneously; a trail is used for approximately 34 months and is then temporarily abandoned for the same period of time. A hunter changed hunting trails according to his or her perception of the decrease in the catch per unit effort and the scarcity of mammal signs. Trails that were located along rivers were only used during the dry season because of difficulty of access.

Hunting pressure was not constant throughout the year. The number of active hunters peaked during the dry season (July to September) and in December. During the dry season, the number of hunters increased by approximately $30 \%$, with occasional hunters (Okouyi 2006) only active while spending their holidays in the village. In contrast, of the 16 hunters registered in 1 year, only two were active year round. The others were active for up to 7 months and were then busy with other activities outside the village. In the study region, villagebased hunters were mainly busy with gold mining and left the village for several months to go to gold camps near Bélinga, located approximately $70 \mathrm{~km}$ northeast of Makokou. Some men were also busy helping the women with agricultural activities, mainly slash and burn during the dry season.

The catch was highest during the main dry season (August and September) and was particularly low during the main rainy season (October to December) and the short dry season (December to February). Animals that were killed for cultural ceremonies during the dry season represented one-half of the total annual offtakes. Biomass extracted from the forest was also highest in August and September because both the number of hunters and the number of hunting trips increased and because larger animals such as red river hog were especially sought.

The spatial distribution of hunting pressure in Ntsieté also varied throughout the year. In July, August, September, and December, $>20 \%$ of hunting activities were practiced at $>10 \mathrm{~km}$ from the village. During the rest of the year, hunting was mainly practiced close to the village. In January, February, and March, at least 50\% of hunting activities occurred at $<2 \mathrm{~km}$ from the village.

Hunting pressure was dissimilar among the forest types. In Ntsieté, hunters recognize six main habitats in which to hunt: issuaka, mature forest with a clear or semi-clear understory on clay soils $(51 \%$ of the village territory); iboutou, old secondary regrowth $(21 \%)$; kouba, agricultural fields $(5 \%)$; indombo, swamps and marshy forests on sandy soils rich with organic matter $(5 \%)$; roads $(1 \%)$; and rivers $(2 \%)$. The hunters reported that mature forest was preferred for hunting because visibility is higher than in habitats that have very dense understory, where walking off the trails is more difficult. Sixty-nine percent of the animals killed came from mature forest. During the rainy season, swamps and marshy forest were only crossed through; during the dry season, these habitats were particularly used by hunters. Despite the hunters' claim of preference for mature forest, disturbed and marshy forests had higher hunting pressure according to the index of hunting pressure for each habitat (disturbed forest: $I_{h}=1.9,27 \%$; marshy forest: $I_{h}=2.3,33 \%$; Figure 3 ).

The nature of the offtakes also varied by forest type (Figure 4). Disturbed forests offered the greatest diversity of species: 15 regularly hunted species, mainly blue duiker, rodents, and small monkeys. Rivers were particularly rich in reptiles and 
Fig. 2. Village boundaries, hunting trails, and hunting camps in Ntisieté.

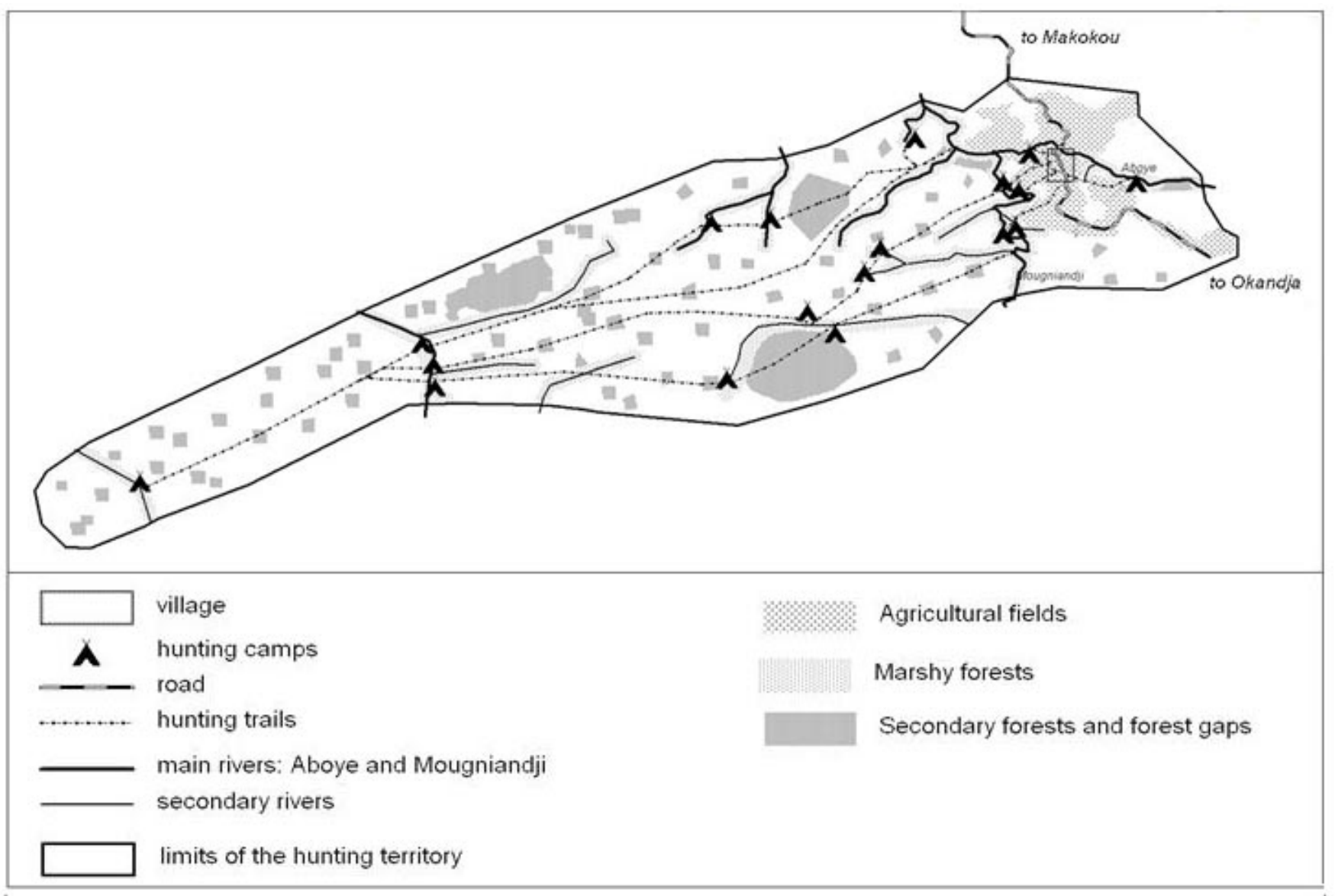

ungulates such as water chevrotain (Hyemoschus aquaticus) and sitatunga. Mature forest sheltered mainly ungulates such as duikers and red river hog, as well as small monkeys. Agricultural fields offered rodents and small ungulates (mainly blue duiker); roads offered small carnivores and birds.

\section{Assessing hunting impact}

We recorded approximately 23 hunted species in Ntsieté. The most hunted species were blue duiker (37.5\% of total offtakes), small diurnal monkeys $(23.5 \%)$, and red river hog $(12.3 \%)$. Our comparison of previous (Lahm 1993) and current offtakes indicates that the proportion of blue duiker remained stable, whereas the proportions of red river hog, Peter's duiker, and small diurnal monkeys were significantly higher in 2006-2007 than in the late 1980s (red river hog: $\chi^{2}=21.026, p<0.0001$; Peter's duiker: $\chi^{2}=6.923, p=0.009$; monkeys: $\chi^{2}=7.47$. $p=0.006$; Figure 5). Offtakes of African brushtailed porcupine (Atherurus africanus; $\chi^{2}=6.556$, $p=0.01)$ and water chevrotain $\left(\chi^{2}=17.7, p<\right.$ 0.0001 ) were significantly lower in 2006-2007 than in the late $1980 \mathrm{~s}$.

The index of kills $\left(I_{d}\right)$ shows that African brushedtailed porcupine was more likely killed at $<2 \mathrm{~km}$ and never at $>5 \mathrm{~km}$ from the villages (Figure 6). Blue duiker was killed at all distances from the village. Bay and Peter's duiker were more likely killed at $>5 \mathrm{~km}$ from the village, but Peter's duiker was more often killed near the village than was bay duiker. Small diurnal monkeys and red river hog were usually killed at $>10 \mathrm{~km}$ from the village. 
Fig. 3. Index of hunting pressure (I) in each habitat type in Ntsieté hunting territory.

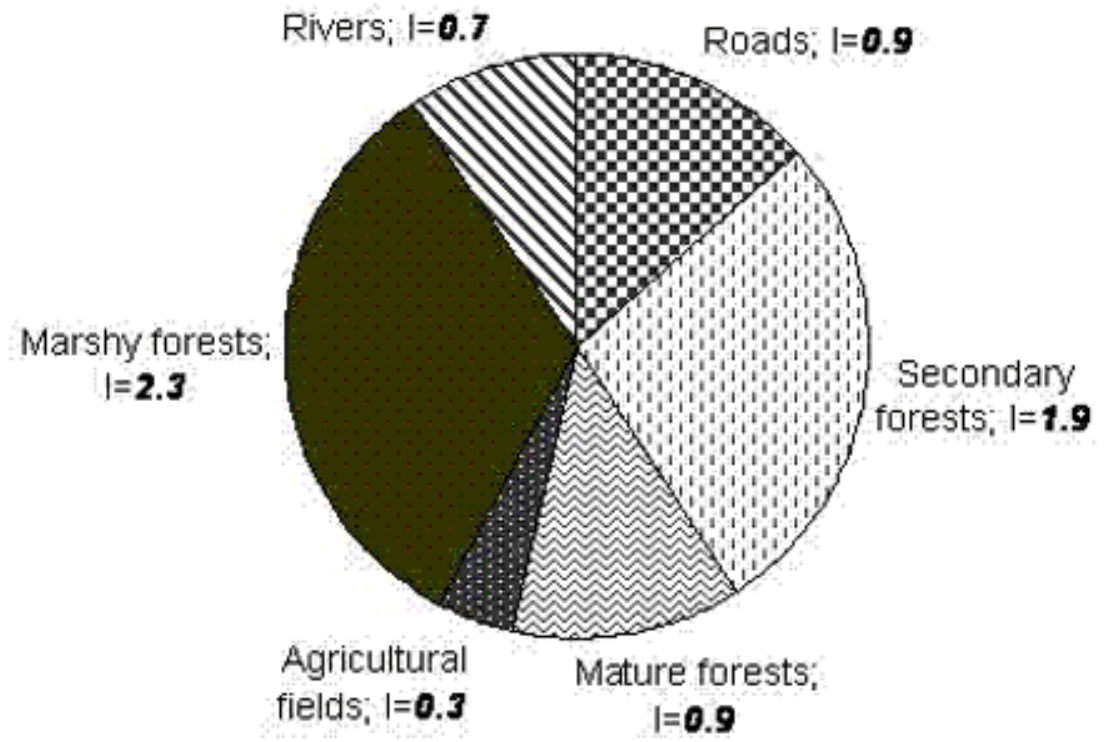

According to Robinson and Redford's (1991) index of sustainability (Table 1), hunting offtakes in Ntsieté are below sustainable limits, expect for three duiker species: blue, bay, and Peter's. This is not proof in itself that hunting is sustainable (see Slade et al. 1998, Milner-Gulland and Resit Akçakaya 2001, and van Vliet and Nasi $2008 a$ for discussions of the weaknesses of Robinson and Redford's index), but rather is additional evidence in the bundle of proof about sustainability obtained using our approach.

\section{DISCUSSION}

In the last 15 years, hunting patterns in northeast Gabon have changed rapidly, mainly because of the spread of gun hunting. Lahm (1993) reported that snares were more commonly used than guns in the late 1980s. Each hunter had an average of 105 cable snares permanently placed year round. In 20062007 , the mean number of snares per hunter was 15 , and $85 \%$ of the hunting trips registered in Ntsieté were done using guns. When snare hunting was more common, hunters went hunting every 3 days (Lahm 1993), probably to maximize kills and minimize losses. Now, with the prominence of guns, the rhythm of hunting is very variable, with periods during which hunters go to the forest every day and long periods during which they are occupied by other activities. The widespread adoption of hunting with guns has serious implications for the nature of offtakes, giving increased opportunities to hunt larger animals, mainly red river hog (mean weight: $80 \mathrm{~kg}$ ) and red duiker (mean weight: $20 \mathrm{~kg}$ ), and arboreal animals such as small diurnal monkeys. In contrast, offtakes of African brush-tailed porcupine have decreased, likely with the decrease in snare hunting.

Our results show that hunting in villages of northeast Gabon is practiced both for local consumption $(60 \%$ of the catch) and income (40\%) to cover basic family expenses. In the late 1980s, Lahm (1993) observed that $30 \%$ of the villagers consumed all of the animals that they killed, and $70 \%$ of them sold two-thirds of their kills and ate one-third. There is therefore no clear trend for a shift from subsistence to commercial hunting as has been demonstrated for other regions of Africa (de Merode et al. 2004). The poor state of roads in the study area was clearly a limiting factor for the commercialization of bushmeat. As has been shown in other regions, hunting pressure is highest along roads (Blom et al. 
Fig. 4. Types of animals killed in each habitat type in Ntsieté.

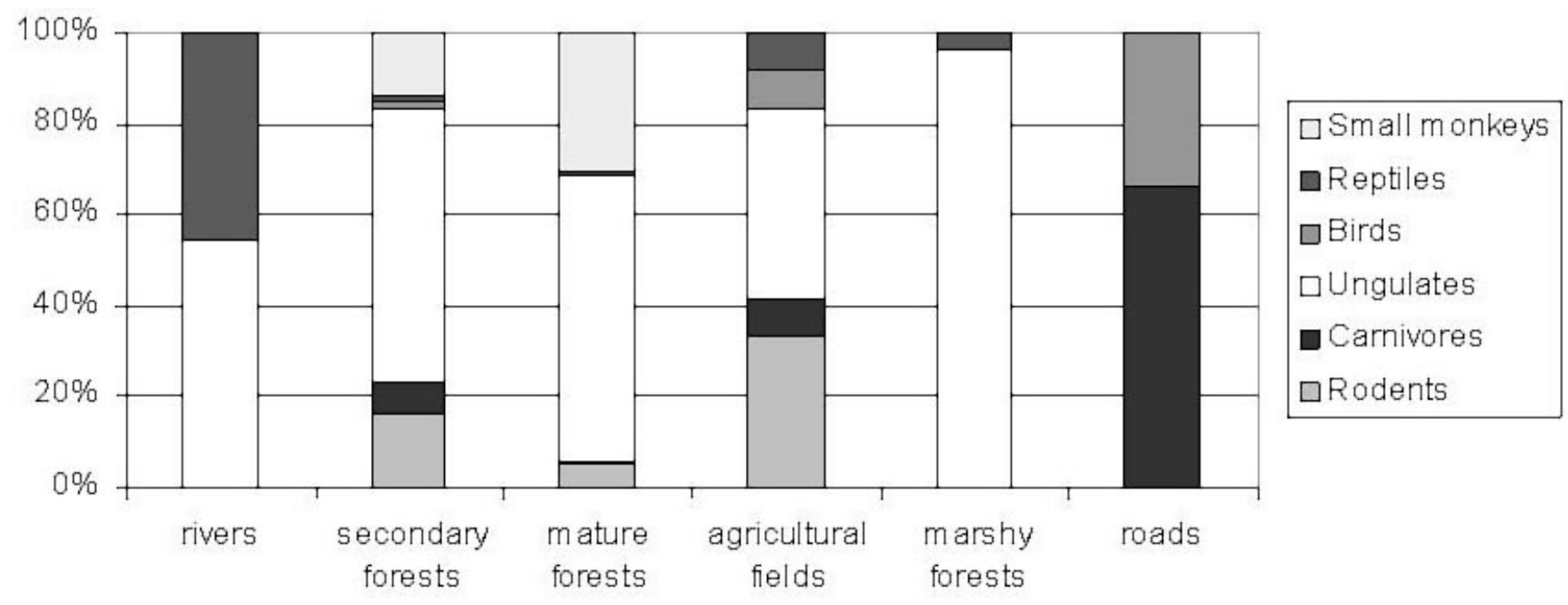

2005, Laurance et al. 2006, van Vliet and Nasi $2008 b$ ). In the Ogooué-Ivindo Province, the improvement of roads will probably greatly modify hunting patterns and increase commercial hunting.

Cultural factors explain the temporal variation in hunting activities. Hunting is more important during the dry season than during the wet season because circumcision ceremonies are organized during the dry season. At that time of year, most hunters are young men from the cities who return to the villages for their holidays. Hunters organize themselves into groups to stay in hunting camps for 3-9 days, and hunting occurs far from the villages. The animals that are killed during these traditional festivities are either used for food or have symbolic value; for example, the skin of servaline genet (Genetta servalina) is used for healing or ritual purposes (Sassen and Wan 2006). The rest of the year, men go hunting for only 1 day and hunt enough for their own family's consumption. Occasionally, the surplus is sold to people in passing vehicles. Socioeconomic factors also explain the variability in hunting. In December, hunting is frequently practiced to earn cash for the New Year festivities. The number of active hunters varies because, when they have a good opportunity, most village-based hunters leave the village for gold camps, and occasional hunters only come to the village during the dry season. The temporal and spatial variability in hunting activities ensures the conservation of areas that are not hunted within the hunting territory, e.g., those that are located far from hunting trails or trails that are not hunted in certain seasons. The populations of some mammal species in these "sink" areas are likely to be maintained by animals migrating from potential "sources." Novaro et al. (2000) found that dispersal could have a key role in rebuilding animal populations that were depleted by hunting. For most hunted mammal species in Central Africa, little information is available on their dispersal patterns. Further knowledge of dispersal parameters related to seasonality, sex, age, and landscape structure is necessary to determine the influence of dispersal on the sustainability of hunting.

Differences in hunting pressure in different habitat types are explained by hunters' preferences, as well as the spatial distribution of habitats and the ease of access. Despite hunters' preferences for mature forest, disturbed forest has higher hunting pressure because this habitat surrounds the villages, whereas mature forest is only present at $>2 \mathrm{~km}$ from villages. Marshy forest is particularly used during the dry season, when many mammal species look for wet areas. Habitat preferences by hunters have also been described for net hunters in Central African Republic (Noss 1995). Degraded forest such as secondary regrowth supplies $20 \%$ of the animals 
Fig. 5. Comparison of offtakes for each species between the late 1980s and 2006-2007 in villages in northeast Gabon.

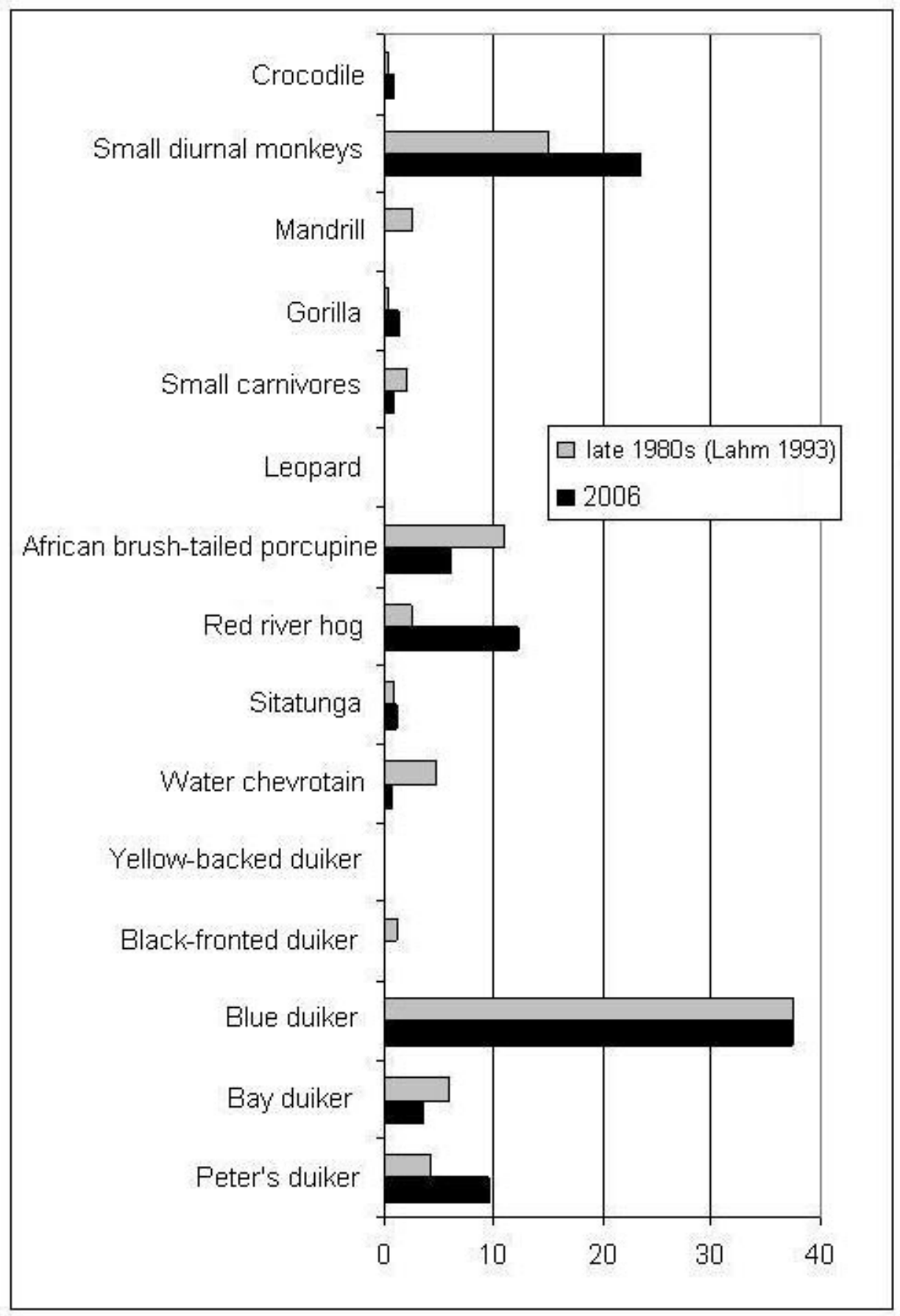


Fig. 6. Index of kills (Id) at various classes of distance from a village for six species.
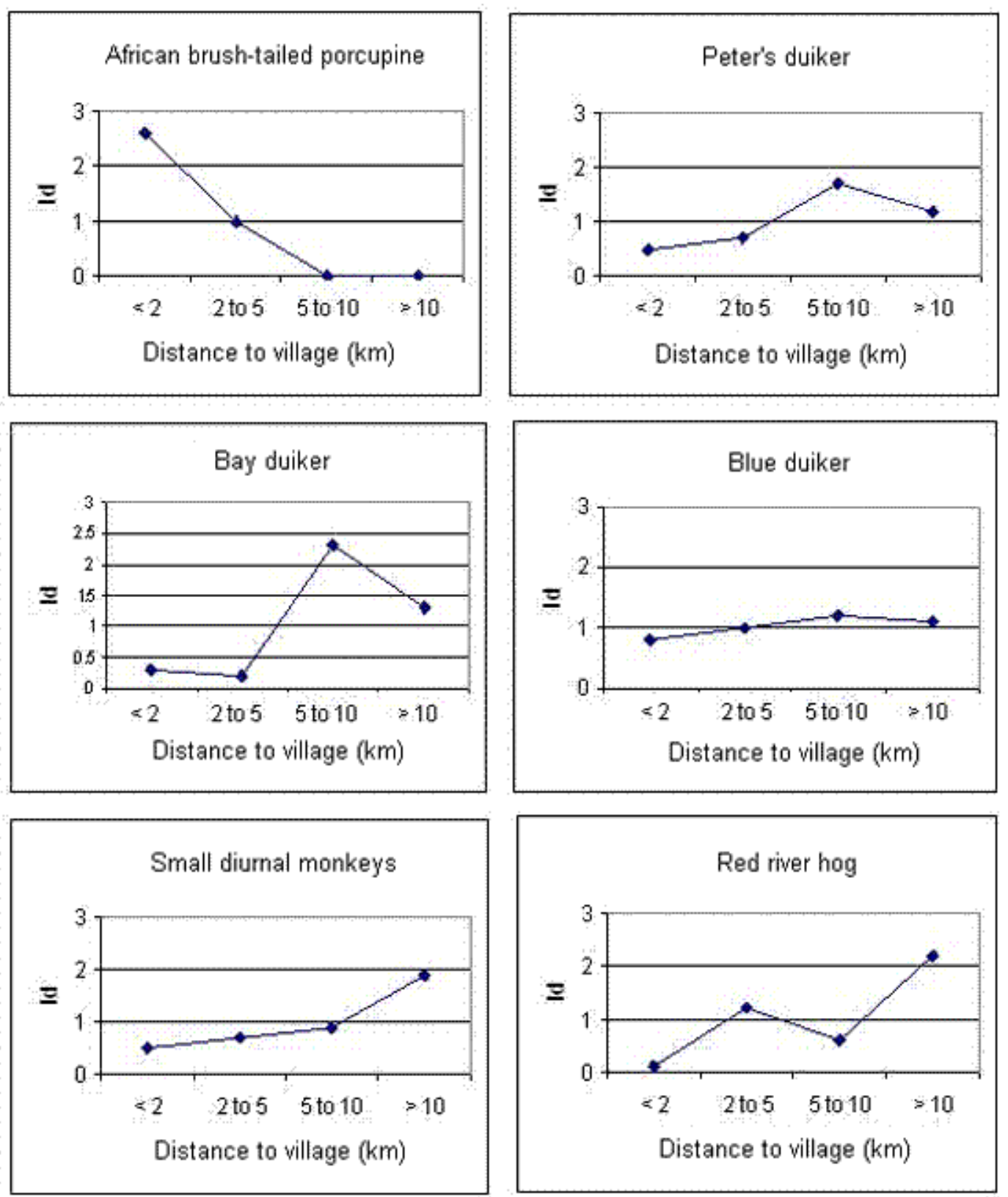

killed and the greatest diversity of species at short distances from the villages. Mature forest supplies species with the greatest commercial value, e.g., red river hog, and is a convenient source of meat for traditional ceremonies. Therefore, the conservation of such undisturbed or lightly disturbed habitat is essential to meet local economic and cultural needs.

Our results indicate that the forests of northeast Gabon are still able to offer large-bodied species to hunters at reasonable distances from villages. Global annual offtakes for blue duiker, Peter's duiker, and bay duiker do not exceed the maximum sustainable yield (MSY). In Ntsieté, only nine African brush-tailed porcupine were killed between 
March 2006 and February 2007, whereas Feer (1996) estimated the MSY for this species at $44 \mathrm{~kg}$ $\mathrm{km}^{-2} \mathrm{yr}^{-1}$ or 480 individuals in $44.5 \mathrm{~km}^{2}$. Our results suggest that there is potential to increase the hunting pressure on resistant species such as blue duiker and African brush-tailed porcupine. As has already been shown in other areas, these two species are still abundant in hunted areas close to villages where hunting has been practiced for $>50 \mathrm{yr}$ (Lahm 1996, Muchaal and Ngandjui 1999, Hart 2000). In contrast, careful attention needs to be given to larger species. Despite offtakes below the MSY, bay duiker and Peter's duiker were mostly killed at $>5$ $\mathrm{km}$ from the villages. Van Vliet et al. (2007) found that bay duiker is very vulnerable to hunting and has been locally depleted near the Ipassa Research Station, northeast Gabon. Hunting pressure on small diurnal monkeys and red river hog has increased significantly in the last $15 \mathrm{yr}$, and these species are now mainly found at $>10 \mathrm{~km}$ from the villages.

Unlike other African regions where mammals have been dramatically depleted by hunting activities, Gabon's natural richness offers a great opportunity to implement hunting management systems that meet local population needs, as well as conservation goals. Further research on information and learning systems within the community and whether they affect harvesting, harvest sustainability, or any form of adaptive management would be a rich baseline from which to elaborate participatory hunting management plans involving factors such as prohibited species, quotas, hunting zones, hunting calendars, and hunting techniques. These should be discussed at a local level to identify possible solutions to maintain the population levels of the more critical species.

Based on our combined approach applied to different sites and contexts, we envision a revision of the Gabonese forest code, which currently lacks technical and social legitimacy. For example, the current Gabonese forest code (law 16/01) forbids hunting at night with guns, cable snare hunting, and hunting from 15 September to 15 March. Therefore, $48 \%$ of the animals killed are hunted illegally: $30 \%$ are hunted using illegal methods, and $34 \%$ are hunted in banned periods. Red river hog is integrally protected by the Gabonese forest code, but represent $41.3 \%$ of the income generated in the bushmeat market of Makokou (Okouyi 2006). Given the dependence of local populations on bushmeat as a source of protein and the quasi-technical impossibility to replace wild meat with domestic meat, such laws that equate to blanket interdiction have no chance of implementation. The law is also flawed from an ecological and conservation viewpoint because species like bay duiker and small diurnal monkeys are not protected, although they are known to be vulnerable and thus need specific hunting regulations for their protection.

Responses to this article can be read online at:

http://www.ecologyandsociety.org/voll3/iss2/art33/responses/

\section{Acknowledgments:}

We are particularly grateful to all of the hunters that voluntarily participated in the study and their families, who welcomed us into their homes. We thank the Research Institute of Tropical Ecology (IRET) and Centre National de la Recherche Scientifique et Technologique (CENAREST) for welcoming us at the Ipassa Research Station. This document was produced with the financial assistance of the IFAD and European Union; the views expressed herein can in no way be taken to reflect their official opinion.

\section{LITERATURE CITED}

Anonymous. 2005. Recensement de la population gabonaise. Journal Officiel de la République Gabonaise 2.

Bakarr, M. I., G. A. B da Fonseca, R. Mittermeir, A. B. Rylands, and K. W. Painemilla. 2001. Hunting and bushmeat utilization in the African rain forest: perspectives toward a blueprint for conservation action. Conservation International, Washington, D.C., USA. Available online at: http:/ /science.conservation.org/portal/server.pt/gateway/ PTARGS $0124186 \quad 12530700 \quad 0 \quad 18 /$ bushmeat.pdf

Blom, A., R. van Zalinge, I. M. A. Heitkönig, and H. H. T. Prins. 2005. Factors influencing the distribution of large mammals within a protected central African forest. Oryx 39(4):381-388.

Bousquet, F., C. Le Page, I. Bakam, and A. Takforyan. 2001. Multiagent simulations of hunting wild meat in a village in eastern Cameroon. Ecological Modelling 138(1-3):331-346. 
Bowen-Jones, E., D. Brown, and E. Robinson. 2002. Assessment of the solution-orientated research needed to promote a more sustainable bushmeat trade in Central and West Africa. Report for the Department for Environment, Food, and Rural Affairs, Wildlife and Countryside Directorate, London, UK. Available online at: www.defra.gov.u k/wildlife-countryside/resprog/findings/bushmeat.pdf

Caughley, G., and C. J. Krebs. 1983. Are big mammals simply little mammals writ large? Oecologica 59(1):7-17.

Cowlishaw, G., S. Mendelson, and J. M. Rowcliffe. 2004. The bushmeat commodity chain: patterns of trade and sustainability in a mature urban market in West Africa. Wildlife Policy Briefing Number 7. Overseas Development Institute, London, UK. Available online at: Www.Z oo.cam.ac.uk/ioz/people/Publications/2004\%200DI\% 20Wildlife\%20Policy\%20Briefing.pdf.

de Merode, E., K. Homewood, and G. Cowlishaw. 2004. The value of bushmeat and other wild foods to rural households living in extreme poverty in Democratic Republic of Congo. Biological Conservation 118(5):573-581.

Delvingt, W., M. Dethier, P. Auzel, and P. Jeanmart. 1997. La chasse villageaoise Badjoué, gestion coutumière durable ou pillage de la ressource gibier? Pages 65-92 in W. Delvingt, editor. La forêt des hommes: terroirs villageois en forêt tropicale africaine. Presses Agronomiques de Gembloux, Gembloux, Belgium.

Dethier, M. 1995. Etude chasse. Projet ECOFACComposante Cameroun. Ministry of the Environment, Yaoundé, Cameroon, and ECOFAC, Brussels, Belgium. Available online at: http://www.ecofac.org/ Biblio/TelechargementSommaire.htm.

Dethier, M., and A. Ghuirghi. 1999. Etude de la chasse villageoise dans le secteur Ouest (route Mambélé-Ndelé) de la zone d'intervention du projet ECOFAC. Projet ECOFAC-Composante Republique Centrafricaine. Ministry of the Environment, Water, Forests, Hunting, and Fish, Bangui, Central African Republic, and ECOFAC, Brussels, Belgium. Available online at: http://www.ecofac.org/ Biblio/TelechargementSommaire.htm.
Fa, J. E., D. Currie, and J. Meeuwig. 2003. Bushmeat and food security in the Congo Basin: linkages between wildlife and people's future. Environmental Conservation 30(1):71-78.

Fa, J. E., J. E. Garcia Yuste, and R. Castelo. 2000. Bushmeat markets on Bioko Island as a measure of hunting pressure. Conservation Biology 14 (6):1602-1613.

Fa, J. E., J. Juste, J. Perez del Val, and J. Castroviejo. 1995. Impact of market hunting on mammal species in Equatorial Guinea. Conservation Biology 9(5):1107-1115.

Fa, J. E., C. A. Peres, and J. Meeuwig. 2002. Bushmeat exploitation in tropical forests: an intercontinental comparison. Conservation Biology 16(1):232-237.

Fa, J. E., S. F. Ryan, and D. J. Bell. 2005. Hunting vulnerability, ecological characteristics and harvest rates of bushmeat species in afrotropical forests. Biological Conservation 121(2):167-176.

Feer, F. 1993. The potential for sustainable hunting and rearing of game in tropical forests. Pages 691-708 in C. M. Hladik, A. Hladik, O. F. Linares, H. Pagezy, A. Semple, and M. Hadley, editors. Tropical forests, people and food: biocultural interactions and applications to development. UNESCO, Paris, France.

Feer, F. 1996. Les potentialités de l'exploitation durable et de l'élevage du gibier en zone forestière tropicale. Pages 1039-1060 in C. M. Hladik, A. Hladik, H. Pagezy, O. F. Linares, G. J. A. Koppert, and A. Froment, editors. L'alimentation en forêt tropicale: interactions bioculturelles et perspectives de développement. UNESCO, Paris, France.

Hart, J. A. 2000. Impact and sustainability of indigenous hunting in the Ituri Forest, Congo-Zaïre: a comparison of unhunted and hunted duiker populations. Pages 106-153 in J. G. Robinson and E. L. Bennet, editors. Hunting for sustainability in tropical forests. Columbia University Press, New York, New York, USA.

Lahm, S. A. 1993. Ecology and economics of human/wildlife interaction in northeastern Gabon. Dissertation. New York University, New York, New York, USA. 
Lahm, S. A. 1996. Utilisation des ressources forestières et variations locales de la densité du gibier dans la forêt du nord est du Gabon. Pages 383-401 in C. M. Hladik, A. Hladik, H. Pagezy, O. F. Linares, G. J. A. Koppert, and A. Froment, editors. L'alimentation en forêt tropicale: interactions bioculturelles et perspectives de développement. UNESCO, Paris, France.

Laurance, W. F., B. M. Croes, L. Tchignoumba, S. A. Lahm, A. Alonso, M. E. Lee, P. Campbell, and C. Ondzeano. 2006. Impacts of roads and hunting on Central African rainforest mammals. Conservation Biology 20(4):1251-1261.

Milner-Gulland, E. J., and H. R.Akçakaya. 2001. Sustainability indices for exploited populations. Trends in Ecology and Evolution 16(12):686-692.

Muchaal, P. K., and G. Ngandjui. 1999. Impact of village hunting on wildlife populations in the western Dja Reserve, Cameroon. Conservation Biology 13(2):385-396.

Nasi, R., D. Brown, D. Wilkie, E. Bennett, C. Tutin, G. van Tol, and T. Christophersen. 2008. Conservation and use of wildlife-based resources: the bushmeat crisis. CBD Technical Series Number 33. Secretariat of the Convention on Biological Diversity, Montreal, Canada, and Center for International Forestry Research, Bogor, Indonesia. Available online at: www.cbd.int/doc/publications/ cbd-ts-33-en.pdf.

Ngandjui, G., and C. P. Blanc. 2000. Effects of hunting on mammalian (Mammalia) populations in the western sector of the Dja Reserve (southern Cameroon). Game and Wildlife Science 17 (2):93-113.

Noss, A. J. 1995. Duikers, cables and nets: cultural ecology of hunting in a Central African forest. Dissertation. University of Florida, Gainesville, Florida, USA.

Noss, A. J. 1998a. The impacts of BaAka net hunting on rainforest wildlife. Biological Conservation 86(2): 161-167.

Noss, A. J. 1998b. The impacts of cable snare hunting on wildlife populations in the forests of the Central African Republic. Conservation Biology 12 (2):390-398.
Noss, A. J. 2000. Cable snares and nets in the Central African Republic. Pages 282-304 in J. G. Robinson and E. L. Bennet, editors. Hunting for sustainability in tropical forests. Columbia University Press, New York, New York, USA.

Novaro, A. J., K. H. Redford, and R. E. Bodmer. 2000. Effect of hunting in source-sink systems in the Neotropics. Conservation Biology 14 (3):713-721.

Okouyi, J. 2006. Savoirs locaux et outils modernes cynégétiques: développement de la filière commerciale de viande de brousse à Makokou (Gabon). Dissertation. L'Université d'Orléans, Orléans, France.

Robinson, J. G., and K. H. Redford. 1991. Sustainable harvest of Neotropical forest animals. Pages 415-429 in J. G. Robinson and K. H. Redford, editors. Neotropical wildlife use and conservation. University of Chicago Press, Chicago, Illinois, USA.

Sassen, M., and M. Wan. 2006. Etude pluridisciplinaire du paysage (MLA): a la découverte de la biodiversité, de l'environnement et des perspectives des populations locales dans les paysages forestiers, Makokou, Gabon. Rapport pour le projet PSVAP composante 2. CIFOR and IRET/ CENAREST, Libreville, Gabon.

Slade, N. A., R. Gomulkiewicz, and H. M. Alexander. 1998. Alternatives to Robinson and Redford's method of assessing overharvest from incomplete demographic data. Conservation Biology 12(1):148-155.

van Vliet, N., and R. Nasi. 2008a. Why do biological models fail to assess properly the sustainability of duiker (Cephalophus spp.) hunting in Central Africa? Oryx 42(3):392-399.

van Vliet, N., and R. Nasi. 2008b. Mammal distribution in a Central African logging concession area. Biodiversity and Conservation 17(5):1241-1249.

van Vliet, N., R. Nasi, L. Emmons, F. Feer, P. Mbazza, and M. Bourgarel. 2007. Evidence for the local depletion of bay duiker (Cephalophus dorsalis), within the Ipassa Man and Biosphere Reserve, northeast Gabon. African Journal of Ecology 45(3):440-443. 
Vandeweghe, J. P. 2006. Ivindo et Mwagna: eaux noires, forêts vierges et baïs. Wildlife Conservation Society, Libreville, Gabon.

Wilkie, D. S., and J. F. Carpenter. 1999. Bushmeat hunting in the Congo Basin: an assessment of impacts and options for mitigation. Biodiversity and Conservation 8(7):927-955.

Wilkie, D. S., M. Starkey, K. Abernethy, E. Nstame Effa, P. Telfer, and R. Godoy. 2005. Role of prices and wealth in comsumer demand for bushmeat in Gabon, Central Africa. Conservation Biology 19(1):268-274.

Willcox, A. S., and D. M. Nambu. 2007. Wildlife hunting practices and bushmeat dynamics of the Banyangi and Mbo people of southwestern Cameroon. Biological Conservation 134(2):251-261. 


\section{APPENDIX 1. Interview questions used to describe hunting practices.}

\section{Hunting Practices}

Hunter's name

Date

Village

How many times per month do you go hunting?

Do you specifically hunt certain species?

Is hunting is a way for you to cover your own consumption or to earn cash? If both, which is the most important motivation for hunting?

Are there any perdiods during the year when you do not hunt? Why? Are there any periods during the year when you particularly hunt? Why?

Is season an important factor? Why?

Do you go hunting alone or in groups? How many people are there in a group?

Do you sometimes hunt for someone else? For specific orders?

Where do you hunt during the rainy season? During the dry season?

Iboutou (secondary forest)

Kouba (agricultural fields)

Indombo (marshy forest)

Issuaka (mature forest)

Are there seasons when hunting is easier? Why?

Short dry season

Main rainy season

Short rainy season

Main dry season 
How far from the village do you usually go to hunt? $<2 \mathrm{~h}$

$$
\begin{aligned}
& \text { between } 2 \text { and } 5 \mathrm{~h} \\
& \text { between } 5 \text { and } 10 \mathrm{~h} \\
& >10 \mathrm{~h}
\end{aligned}
$$

What weight can one hunter carry on the way back to the village?

What are the different tecniques that you use to hunt?

What animal is the most easy to hunt (using the different techniques mentioned above)?

In what type of forest is it easier to hunt (using the different techniques mentioned above)?

If gun hunting

If snare hunting
Was it easy to buy a gun? Where? How much?

Is it easy to find cartridges? Where? how much?

Can you estimate how many missed shots you have out of 10 cartridges?

What species are easiest to shoot?

Do you use calls to attract animals? When? Where? What animals?

How many snares do you currently have?

How do you choose where and when to place snares? In what type of forest?

At what time of the day do you set snares? How often do you return to check the snares?

How long does a snare line stay in place? What makes you decide to change the location of your snare line?

How much does a snare cable cost?

Imagine that you set 100 snares. How many would have caught an animal by the first day that you returned to check them?

What are the traditional practices that you use before or during hunting? 
APPENDIX 2. Interview questions used to record hunting offtakes every 2 days for each hunter.

\section{Offtakes}
Hunter's name:
Age:
Ethnic group:
Date:

Where did you hunt in the last 2 days?

How many days did you stay?

Did you hunt with gun or snare?

Did you hunt at night or during the day?

\section{If snare hunting:}

How many snares did you set or reset in the last 2 days?

How many snares did you visit?

\section{If gun hunting}

How many and what type of animals did you see?

How many of those animals did you shoot?

How many cartridges did you use?

How many animals did you kill?

\section{Description of hunted animals}

\begin{tabular}{|c|c|c|c|c|c|c|c|c|}
\hline Species & Sex & Forest type & Gun or snare & Night or day & $\begin{array}{l}\text { With or } \\
\text { without dogs }\end{array}$ & $\begin{array}{l}\text { With or } \\
\text { without calls }\end{array}$ & $\begin{array}{l}\text { Name of the } \\
\text { place, river, or } \\
\text { camp }\end{array}$ & $\begin{array}{l}\text { Sold (to whom) or for } \\
\text { own consumption? }\end{array}$ \\
\hline
\end{tabular}

